\title{
Possibility of Developing a Male Sterile Line of Shallot (Allium cepa L. Aggregatum Group) with Cytoplasm from A. galanthum Kar. et Kir.
}

\author{
Ken - ichiro Yamashita and Yosuke Tashiro \\ Faculty of Agriculture, Saga University, Saga 840-8502
}

\begin{abstract}
Summary
In an effort to develop a male sterile line of shallot (Allium cepa L. Aggregatum group), a continuous backcrossing was carried out using $A$. galanthum Kar. et Kir. as a cytoplasm donor and the shallot as a nucleus donor. Meiosis and fertility in the $F_{1}$ hybrids, $B_{1}, B_{2}$, and $B_{3}$ progenies were examined.

The $F_{1}$ hybrids had low pollen fertility, whereas the $B_{1}$ plants were pollen sterile or nearly so; the $\mathbf{B}_{2}$ and $\mathbf{B}_{3}$ plants were completely pollen sterile. Pollen sterility observed in the backcross progenies was attributed to nuclear-cytoplasmic incompatibility because the pollen mother cells in most of these plants underwent normal meiosis. Although the seed fertility varied considerably among the progenies at each backcross generation, it could be improved with the advancement of backcrossing. PCR-RFLP analysis of chloroplast DNA proved that all the backcross progenies had the cytoplasm from $A$. galanthum. These results demonstrate that there is a realizable possibility of developing a male sterile line of shallot using this genetic approach.
\end{abstract}

Key Words: shallot, Allium cepa, Allium galanthum, cytoplasm, male sterile.

\section{Introduction}

Shallot (Allium cepa L. Aggregatum group) is an important vegetable crop in Southeast Asia and is also grown in home gardens in Europe and the United States for its bulbs and green leaves (Ochse,1931; Jones and Mann,1963; Hanelt,1990). Shallot is very similar to the common onion (A. cepa L. Common onion group) with respect to the inflorescence, karyotype, and meiotic behavior. They differ in that the shallot has a small stature, tillers actively, and forms a cluster of small bulbs (Tashiro et al., 1982). In Southeast Asia, the shallot is more popular and useful than is the common onion because of its high adaptability to tropical and subtropical zones. Although propagated vegetatively, shallot has fertile pollen and seed; therefore, it can be easily crossed with the common onion (Atkin,1953; Tashiro et al.,1982) and A. fistulosum L. (Cochran,1942; Tashiro,1984). The shallot germplasm is important as a genetic resource for the improvement of tropical Allium crops. Moreover, the establishment of a true seed shallot and the development of $F_{1}$ cultivars are expected to have many horticultural advantages, such as high efficiency of propagation and high storage ability and shipping quality of seeds. Furthermore, the seedlings could be made virus free and adaptable to mechanical transplanting. The $F_{1}$ cultivars of shallot should have superior agronomic characteristics, such as high uniformity and productivity of bulbs. Male sterile plants are essential to exempt breeders from the difficulty of emasculation and produce large number of the $F_{1}$ seeds. In common onion, the first cytoplasmic male sterile (CMS) line was discovered in cv. Italian Red by Jones and Emsweller (1937) and the mode of its inheritance was reported by Jones and Clarke (1943). After that, some CMS lines were identified and characterized (Berninger, 1965; Schweisguth,1973). Using these CMS lines, many superior $F_{1}$ seeds of common onion have been released. However, no effective male sterile cytoplasm has been found in shallot yet. The aim of this study is to utilize the cytoplasm of $A$. galanthum Kar. et Kir., a wild species in section Cepa, to develop a male sterile line of shallot.

\section{Materials and Methods}

\section{Materials}

First, a strain of $A$. galanthum from the IVT (CPRODLO) of the Netherlands was crossed with a clone of shallot from Thailand to obtain interspecific $F_{1}$ hybrids. A. galanthum was used as a seed parent, and shallot as a pollen parent. The $F_{1}$ hybrids were continuously backcrossed to shallot; the $B_{1}, B_{2}$, and $B_{3}$ progenies were produced. All crossings were made by hand pollination in a screen-covered isolation cage in a greenhouse. The parental plants, $F_{1}$ hybrids, and backcross progenies were observed for meiosis and pollen and seed fertility and analyzed for their chloroplast DNA (cpDNA). 


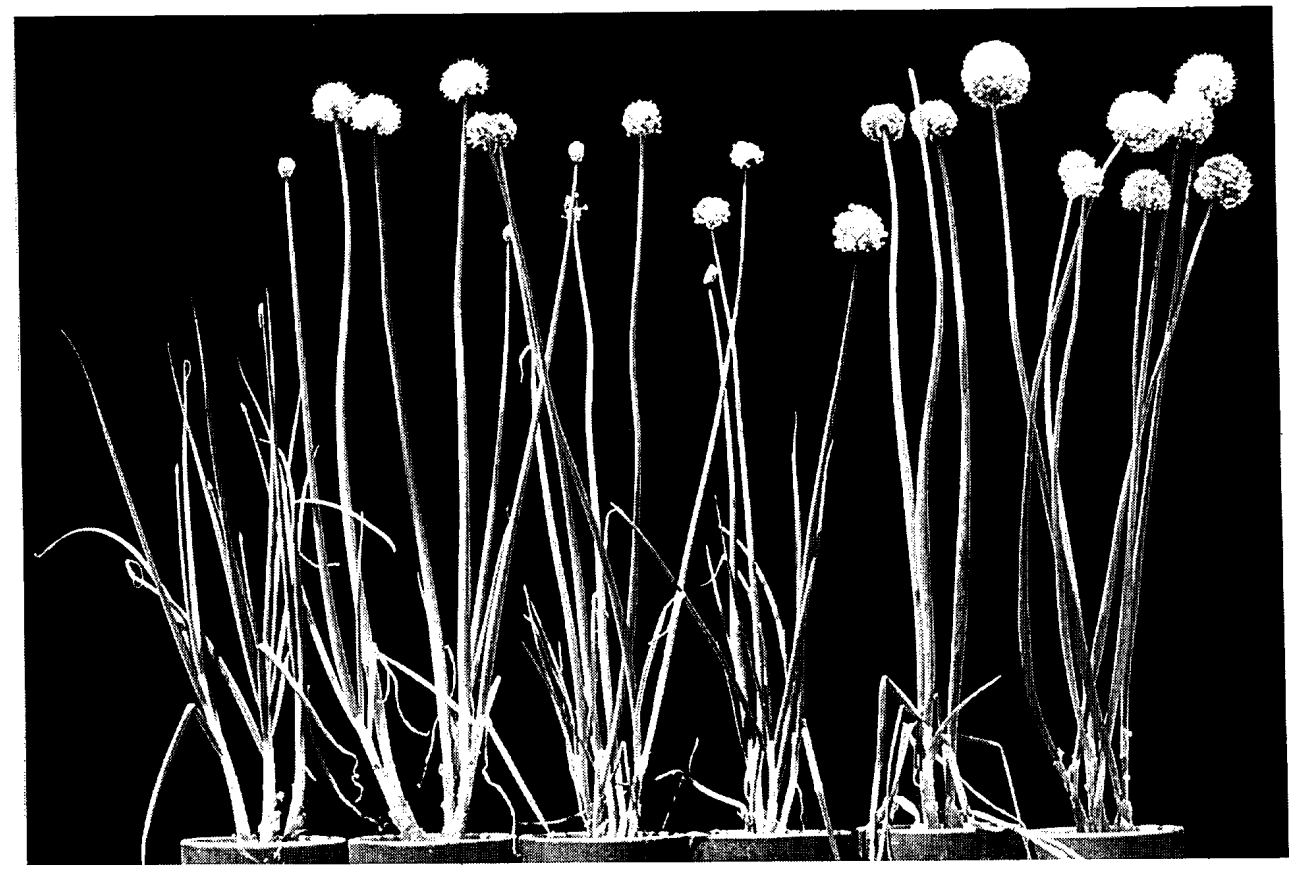

Fig. 1. Plants of A. galanthum, $\mathrm{F}_{1}, \mathrm{~B}_{1}, \mathrm{~B}_{2}$, and $\mathrm{B}_{3}$ progenies and shallot (left to right) at flowering stage.

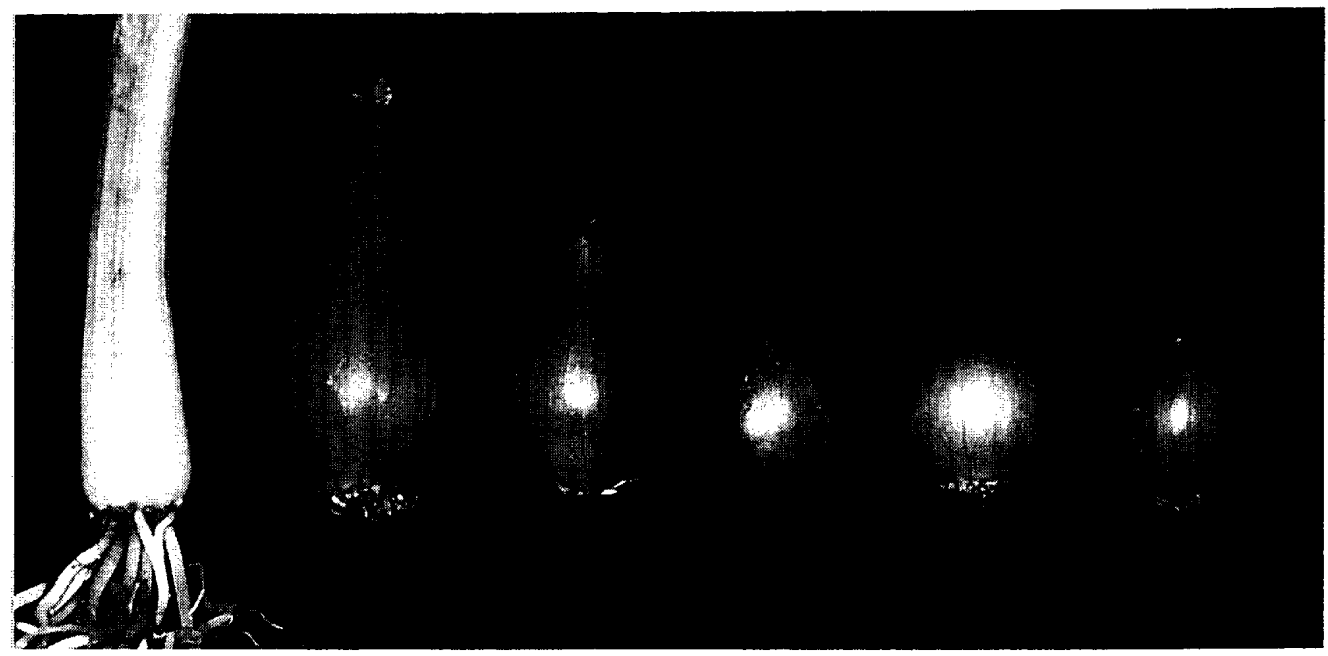

Fig. 2. Basal portion of leaf sheath of $A$. galanthum and bulbs of $\mathrm{F}_{1}, \mathrm{~B}_{1}, \mathrm{~B}_{2}, \mathrm{~B}_{3}$, and shallot (left to right).

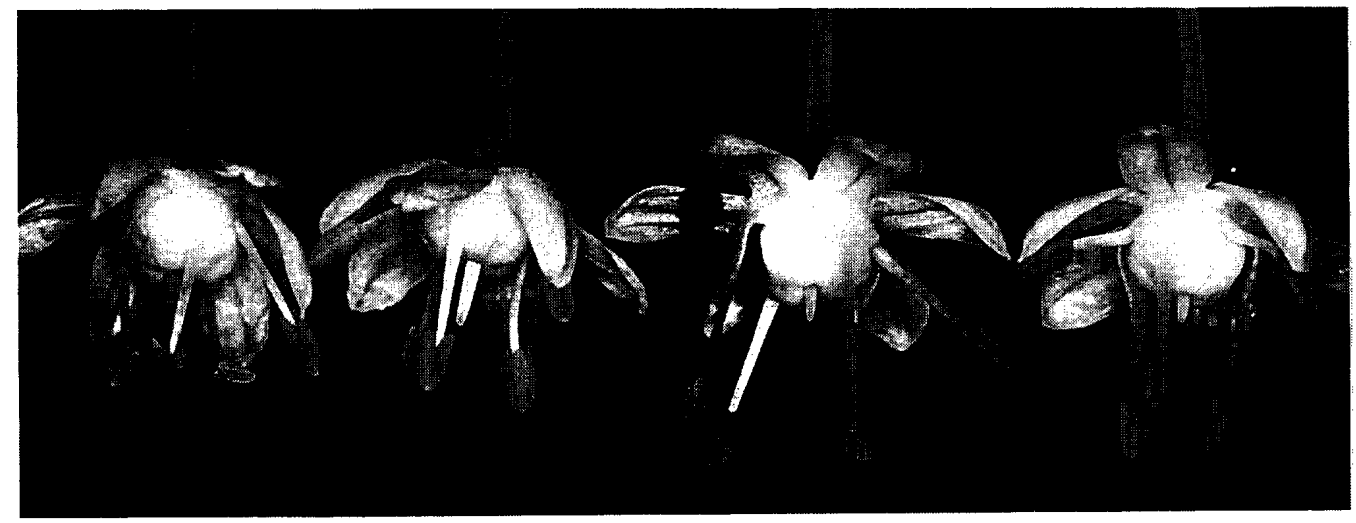

Fig. 3. Florets of shallot (first and second from left) and $B_{3}$ plant (third and fourth)

\section{Meiotic observation}

Meiosis in each generation was examined to estimate the degree of hybridity of the nucleus. Chromosome pairings at metaphase-I in pollen mother cells (PMCs) from fresh anthers were observed by the smear method 
with acetocarmine and the frequency of bivalent chromosomes per PMC was recorded. To observe microsporogenesis, flower buds at different stages were collected and fixed in a mixture of acetic acid and ethyl alcohol (1:3). The microspores in various developmental stages were treated with acetocarmine, smeared as above, and photographed under a light microscope.

\section{Pollen fertility test}

Florets were fixed in a mixture of acetic acid and ethyl alcohol (1:3) just before anthesis. Pollen grains were stained with acetocarmine using the smear method and their percentage fertility was evaluated by their morphology and stainability.

\section{Seed fertility test}

Seed fertility in both parents, $F_{1}$ hybrids, and backcross progenies was estimated from the seed set and the germination rate of seeds when shallot was used as a pollen parent. The seeds were sown on the MS medium without hormone and cultured at $25{ }^{\circ} \mathrm{C}$ in the dark. Germinated seeds were kept at $25{ }^{\circ} \mathrm{C}$ under a $12 \mathrm{hr}$ photoperiod; the seedlings were eventually transplanted into pots.

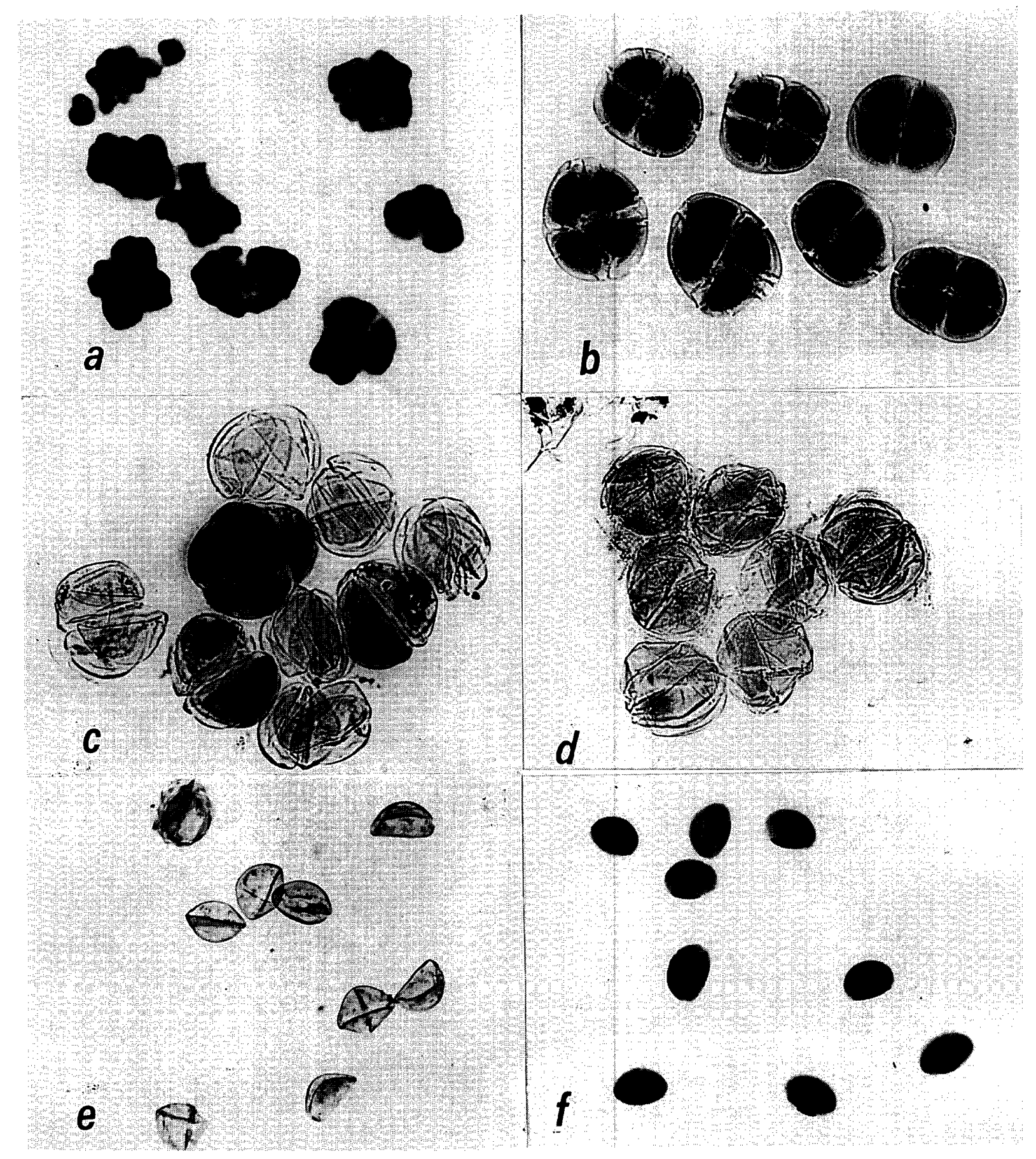

Fig. 4. Chromosome pairing at metaphase $-I$ in a $P M C$ of $B_{3}$ plant (a), tetrads of $B_{3}$ plant (b), degeneration of protoplasms in microspores of $B_{3}$ plant after tetrad stage (c e), and normal pollen grains of shallot (f). 


\section{Analysis of chloroplast DNA}

Total DNA was extracted from fresh leaves, using the procedure described by Hong et al. (1997). The oligonucleotide primers, homologous to the region containing the ribulose-1,5-bisphosphate carboxylase gene $(r b c \mathrm{~L})$ and ORF106, were used for polymerase chain reaction (PCR), according to Arnold et al. (1991). The reaction mixture $(50 \mu \mathrm{l})$ contained $10 \mathrm{mM}$ Tris- $\mathrm{HCl}(\mathrm{pH} 8.3)$, $50 \mathrm{mM} \mathrm{KCl}, 1.5 \mathrm{mM} \mathrm{MgCl}_{2}, 0.1 \mathrm{mM}$ each dATP, dTTP, dCTP and dGTP, 36pmol of each primer, 128ng of total DNA, and 1.25 units of Taq DNA polymerase (TAKARA). DNA amplification was carried out, using the
PROGRAM TEMP CONTROL SYSTEM PC- 800 (ASTEC). The thermal cycler was programmed for $1 \mathrm{~min}$ at $92{ }^{\circ} \mathrm{C}$, followed by 35 cycles of $1 \mathrm{~min}$ at $92^{\circ} \mathrm{C}, 1 \mathrm{~min}$ at $55^{\circ} \mathrm{C}$, and $4 \mathrm{~min}$ at $70{ }^{\circ} \mathrm{C}$, with a final $7 \mathrm{~min}$ at $70^{\circ} \mathrm{C}$. The PCR product was digested with restriction enzyme Alu I and electrophoresed on $1.8 \%$ agarose gel, containing ethidium bromide in $1 \times$ TAE buffer with a size marker. The restriction fragment length polymorphism (RFLP) pattern of PCR product was made visible on a UV transilluminator.

\section{Results and Discussion}

The morphological characters and flowering time of

Table 1. Chromosome pairing at meiotic metaphase-I in PMCs, pollen fertility, and seed fertility in Allium galanthum, shallot, $\mathrm{F}_{1}, \mathrm{~B}_{1}, \mathrm{~B}_{2}$, and $\mathrm{B}_{3}$ progenies.

\begin{tabular}{|c|c|c|c|c|c|}
\hline \multicolumn{2}{|c|}{ Plant material } & Chromosome pairing & $\begin{array}{c}\text { Pollen fertility } \\
(\text { Mean } \pm \text { S.E. })(\%)\end{array}$ & $\begin{array}{l}\text { Seed set }^{2} \\
(\%)\end{array}$ & $\begin{array}{c}\text { Germination rate } \\
(\%)\end{array}$ \\
\hline \multicolumn{2}{|c|}{ Allium galanthum } & $8.0 \Pi$ & $85.0 \pm 7.2$ & 6.1 & 27.3 \\
\hline \multicolumn{2}{|c|}{ Shallot } & $8.0 \mathrm{II}$ & $89.4 \pm 2.0$ & 21.1 & 87.0 \\
\hline \multirow[t]{2}{*}{$\mathrm{F}_{1}$} & $104^{\mathrm{y}}$ & $6.1 \mathrm{II}+3.9 \mathrm{I}$ & $5.0 \pm 1.6$ & 0.04 & 100 \\
\hline & 106 & $5.5 \mathrm{II}+4.9 \mathrm{I}$ & $8.8 \pm 2.1$ & 0 & - \\
\hline \multirow[t]{3}{*}{$\mathbf{B}_{1}$} & $57^{\mathrm{x}}$ & $7.6 \mathrm{II}+0.8 \mathrm{I}$ & 0 & 1.2 & 80.0 \\
\hline & 58 & $6.5 \mathrm{II}+3.1 \mathrm{I}$ & 0 & 0 & - \\
\hline & 1 & $7.8 \mathrm{II}+0.3 \mathrm{I}$ & $6.6 \pm 3.9$ & 2.0 & 77.8 \\
\hline \multirow[t]{7}{*}{$\mathrm{B}_{2}$} & $1^{w}$ & 7.9 II +0.2 I & 0 & 1.6 & 50.0 \\
\hline & 2 & $7.8 \mathrm{II}+0.3 \mathrm{I}$ & 0 & 4.3 & 100 \\
\hline & 3 & $7.8 \mathrm{II}+0.4 \mathrm{I}$ & 0 & 10.0 & 97.5 \\
\hline & 4 & $7.8 \mathrm{II}+0.4 \mathrm{I}$ & 0 & 1.7 & 81.8 \\
\hline & 6 & $8.0 \mathrm{II}$ & 0 & 1.0 & 50.0 \\
\hline & 7 & 7.7 II +0.6 I & 0 & 6.5 & 82.1 \\
\hline & 10 & $7.8 \mathrm{II}+0.4 \mathrm{I}$ & 0 & 7.7 & 95.1 \\
\hline \multirow[t]{17}{*}{$\mathbf{B}_{3}$} & 11 & 7.9 II +0.1 I & 0 & 1.4 & 85.0 \\
\hline & 12 & 7.9 II +0.3 I & 0 & 0.8 & 14.3 \\
\hline & 13 & $6.1 \mathrm{II}+3.9 \mathrm{I}$ & 0 & 0.1 & - \\
\hline & 14 & $3.9 \mathrm{II}+8.2 \mathrm{I}$ & 0 & 0.3 & 66.7 \\
\hline & 15 & 7.7 II +0.6 I & 0 & 1.4 & 87.5 \\
\hline & 16 & $6.0 \mathrm{II}+4.1 \mathrm{I}$ & 0 & 10.2 & 88.2 \\
\hline & 18 & $7.9 \mathrm{II}+0.2 \mathrm{I}$ & 0 & 9.3 & 84.0 \\
\hline & 19 & $8.0 \mathrm{II}$ & 0 & 3.5 & 86.0 \\
\hline & 20 & $7.9 \mathrm{II}+0.2 \mathrm{I}$ & 0 & 3.0 & 75.0 \\
\hline & 21 & $7.9 \mathrm{II}+0.1 \mathrm{I}$ & 0 & 4.4 & 86.3 \\
\hline & 22 & $6.9 \mathrm{II}+2.3 \mathrm{I}$ & 0 & 3.5 & 81.8 \\
\hline & 23 & $7.9 \mathrm{II}+0.3 \mathrm{I}$ & 0 & 2.4 & 77.8 \\
\hline & 24 & $7.6 \mathrm{II}+0.7 \mathrm{I}$ & 0 & 5.0 & 90.2 \\
\hline & 26 & $7.0 \mathrm{II}+2.0 \mathrm{I}$ & 0 & 6.0 & 86.7 \\
\hline & 27 & $7.9 \mathrm{II}+0.3 \mathrm{I}$ & 0 & 3.9 & 83.9 \\
\hline & 28 & $7.9 \mathrm{II}+0.3 \mathrm{I}$ & 0 & 0.2 & 100 \\
\hline & 29 & $5.3 \mathrm{II}+5.4 \mathrm{I}$ & 0 & 2.9 & 56.6 \\
\hline
\end{tabular}

${ }^{z}$ Seed set $=\frac{\text { Number of seeds produced }}{\text { Number of flowers pollinated } \times \text { Number of ovules per flower }(6)} \times 100$

${ }^{\mathrm{y}}$ Seed parent of $\mathrm{B}_{1}$.

${ }^{x}$ Seed parent of $B_{2}$.

${ }^{w}$ Seed parent of $B_{3}$. 
the $\mathrm{F}_{1}$ hybrids were intermediate between $A$. galanthum and shallot. The more backcrossing was repeated, the more the backcross progenies resembled the shallot (Fig. 1). Shallot formed bulbs, but $A$. galanthum did not. All the $F_{1}$ hybrids and backcross progenies formed bulbs; $\mathrm{B}_{2}$ and $\mathrm{B}_{3}$ plants had almost the same bulb morphology as the shallot (Fig. 2). Most of the backcross progenies showed some abnormalities in anther shape and color, i.e. their anthers were more slender than those of shallot (Fig.3). Moreover, their anthers were whitish yellow, whereas those of the shallot were dark green. Tashiro (1984) produced reciprocal $\mathrm{F}_{1}$ hybrids between $A$. fistulosum and shallot; he observed hypoplasia of anthers only in progenies between $A$. fistulosum (seed parent) and shallot (pollen parent). He interpreted this phenomenon as a genetic disharmony between the cytoplasm from $A$. fistulosum and the nuclear genome from shallot. Ulloa $-\mathrm{G}$ et al. (1995) attempted to introduce the cytoplasm of $A$. fistulosum into the common onion as a source of CMS; they reported the presence of morphological abnormalities, including lack of anther, short petal, small pistil, and shortened filament in $B_{1}$ and $B_{2}$ progenies. They concluded that the flower abnormality was evidence of a strong incompatibility between the cytoplasm of $A$. fistulosum and the nucleus of the common onion. The abnormalities of anthers observed in our study may, likewise, be evidence of such genetic disharmony or incompatibility between the cytoplasm and nuclear genome from different species.

Both parents formed eight bivalent chromosomes per PMC (Table 1). The frequency of bivalent chromosomes was lower in the $F_{1}$ hybrids than in the parents. Compared with the $F_{1}$ hybrids, $B_{1}$ and $B_{2}$ progenies had increased bivalent chromosomes, which indicates that nucleus substitution to shallot nucleus progressed gradu- ally with frequency of backcrossing. Although most plants in the $\mathrm{B}_{3}$ generation had improved chromosome pairings, the frequency of bivalent chromosomes varied from 3.9 to 8.0. Desynapsis occurred in plants that showed low frequencies of bivalent chromosomes. These plants may have some genetic factor which induces desynapsis.

Pollen fertility in $F_{1}$ hybrids decreased drastically in comparison with both parents (Table 1). Of the three $\mathrm{B}_{1}$ plants, one possessed low pollen fertility, whereas the other two were completely pollen sterile. All plants in $\mathrm{B}_{2}$ and $\mathrm{B}_{3}$ generations were completely pollen sterile independent of the frequency of bivalent chromosomes per PMC. A possible cause for low pollen fertility in the $\mathrm{F}_{1}$ hybrids is attributed to the hybridity of nuclei. However, it is difficult to relate pollen sterility observed in the backcross progenies to the hybridity of nuclei because these plants exhibited high frequency of bivalent chromosomes (Fig. 4a). Therefore, we attribute the pollen sterility in the backcross progenies to an incompatibility between nucleus and cytoplasm.

Microsporogenesis occurred in all the pollen sterile backcross progenies and resulted in a large number of normal tetrads (Fig. 4b). However, the protoplasm gradually degenerated after the tetrad stage (Fig.4c), finally resulting in empty tetrads or a few empty pollen grains in the anthers (Fig. 4d,e). The empty pollen grains were almost the same size as normal pollen grains of shallot (Fig. 4e,f). Thus, we conclude that the cytoplasm from $A$. galanthum intensely influenced the gene expression of the pollen fertility of shallot at microsporogenesis just after the tetrad stage. Anatomical studies of microsporogenesis in male sterile onions reported by Tatebe (1952), Chauhan (1979), Chauhan and Kinoshita (1980), and Holford et al. (1991) attributed the male

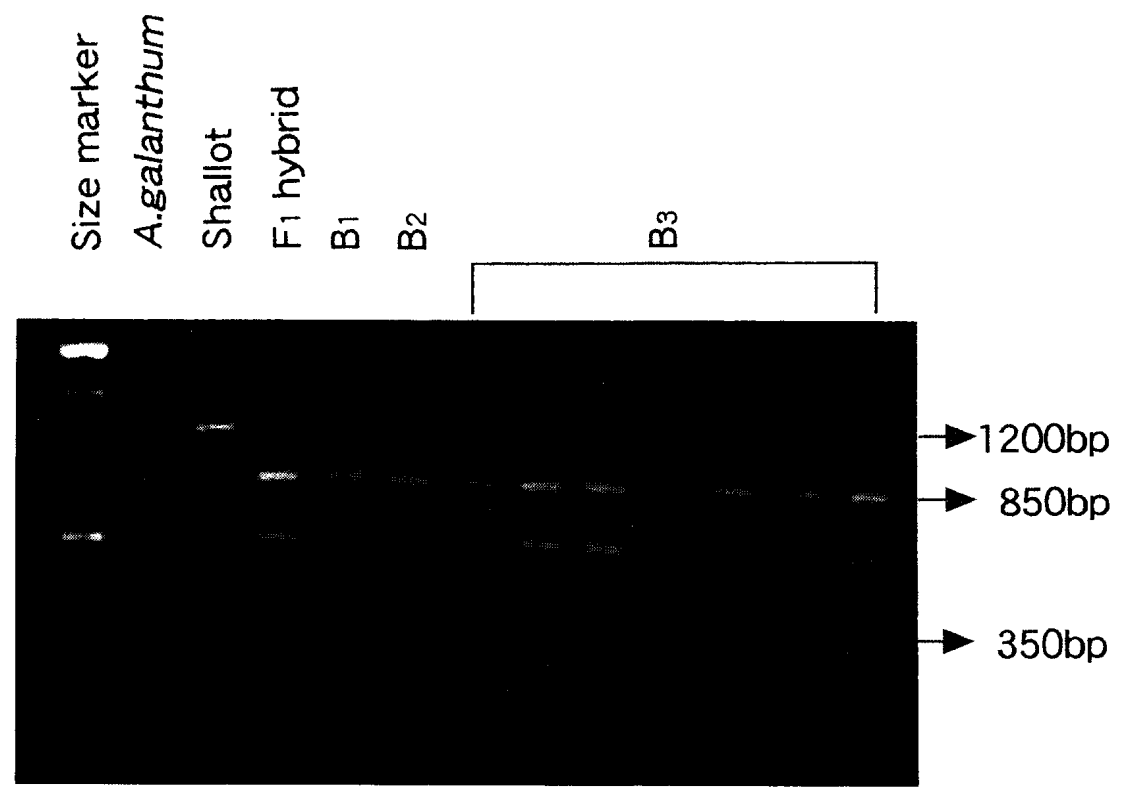

Fig. 5. PCR-RFLP patterns of $r b c L-O R F 106$ region of cpDNA in $A$. galanthum, shallot, $\mathrm{F}_{1}$, and backcross progenies. Amplified DNA fragments were digested with Alu I 
sterility to abnormal tapetal behavior. Hence, further study is necessary to clarify the mechanism of pollen sterility in our backcross progenies.

$\mathrm{F}_{1}$ and $\mathrm{B}_{1}$ plants had seed sets less than $6.1 \%$ in $A$. galanthum (Table 1), whereas seed sets in $\mathrm{B}_{2}$ and $\mathrm{B}_{3}$ generation varied from 1.0 to $10.0 \%$ and from 0.1 to $10.2 \%$, respectively. Seed set improved with frequency of backcrossing. Most of the seeds yielded from the backcross progenies were viable, which reveals that the cytoplasm from $A$. galanthum gently governs the expression of gene(s) concerning the seed fertility of shallot. Ulloa-G et al. (1995) reported that most of $B_{2}$ progenies between $A$. fistulosum and common onion were completely sterile with respect to both pollen formation and seed set. Therefore, the influence of nuclear-cytoplasmic incompatibility on pollen and seed fertility seems to vary with the sources and combinations of nuclei and cytoplasms within Allium.

PCR-RFLP patterns of cpDNA revealed species specific bands of $850 \mathrm{bp}$ and $350 \mathrm{bp}$ in $A$. galanthum and that of 1200bp in shallot (Fig. 5). $F_{1}$ hybrids and all the backcross progenies had the same pattern as $A$. galanthum, which demonstrates that $\mathrm{F}_{1}$ hybrids and the backcross progenies inherited the cytoplasm from it.

Some wild species in Allium have been regarded as genetic resources to improve cultivated species, and they have been crossed with the common onion and $A$. fistulosum to introduce their useful characters (Saini and Davis, 1967, 1969; McCollum, 1974, 1982; van der Meer and de Vries,1990; Kofoet et al.,1990; de Vries et al.,1992a, 1992b; van Raamsdonk et al.,1992). There have been no previous reports on hybridization between $A$. galanthum and shallot, although researchers have crossed $A$. galanthum with the common onion and investigated the fertility of their $\mathrm{F}_{1}$ hybrids (Saini and Davis, 1967, 1969; McCollum, 1971; van Raamsdonk et al., 1992). According to their studies, the $F_{1}$ hybrids obtained from crossing between $A$. galanthum (seed parent) and common onion (pollen parent) had low pollen fertility. Seed fertility of these $F_{1}$ hybrids was generally low, although the detailed data were not reported. McCollum (1971) described a hybrid sterility barrier based on seed sterility in the $\mathrm{F}_{1}$ hybrids between the common onion and A. galanthum or A. pskemense B. Fedtsch. He concluded that this sterility barrier should not prevent the use of these species in onion breeding, but it would cause difficulties in early generations of crosses. Some isolation barriers between Allium species were also mentioned by van Raamsdonk et al. (1992), based on the cross incompatibility and sterility of $F_{1}$ hybrids. In our study, pollen and seed fertility was very low in the $\mathrm{F}_{1}$ hybrids between $A$. galanthum and shallot; therefore, it seems that a severe isolation barrier existed in the $F_{1}$ hybrids. However, once the $B_{1}$ generation was obtained, $\mathrm{B}_{2}$ and $\mathrm{B}_{3}$ generations were easily obtained. Most fertility studies on interspecific crossings in Allium mentioned above finished with the $F_{1}$ or $B_{1}$ generations.
Our results suggest that it is worthwhile to backcross continuously with the different species in Allium even if the $F_{1}$ hybrids or early backcross generations have low seed fertility.

Our data indicate that the cytoplasm from $A$. galanthum significantly influences only the pollen fertility of shallot and that there is a possibility of developing a male sterile line of shallot with the cytoplasm from $A$. galanthum. Additional backcrosses are in progress. Our study also suggests that the cytoplasms of other wild species may be useful genetic resources for the breeding in Allium. Currently, the cytoplasms of other wild species, A. oschaninii O. Fedtsch., A. vavilovii M. Pop. et Vved., and $A$. altaicum Pall., are being explored.

\section{Literature Cited}

Arnold, M. L., C. M. Buckner and J. J. Robinson. 1991. Pollen-mediated introgression and hybrid speciation in Louisiana irises. Proc. Natl. Acid. Sci. USA 88: 1398 1402.

Atkin, J. D. 1953. Genetic and cytological studies of the Allium cepa $\times$ A. ascalonicum. Ph. D. Thesis. Univ. Calif., Davis.

Berninger, B. 1965. Contribution to the study of male sterility in the onion (Allium cepa L.). Ann. Amelior. Plant. 15: 183- 199.

Chauhan, S. V. S. 1979. Development of endothecium in relation to tapetal behavior in some male sterile plants. Phytomorph. 29: 245-251.

Chauhan, S. V. S. and T. Kinoshita. 1980. Anther ontogeny in genic, cytoplasmic and chemically induced male sterile plants. Japan. J. Breed. 30: 117- 124.

Cochran, F.D. 1942. Cytogenetic studies of the species hybrid $A$. fistulosum and $A$. ascalonicum and its backcross progenies. Ph. D. Thesis. Univ. Calif., Davis.

de Vries, J. N., W. A. Wietsma and T. de Vries 1992 a. Introgression of leaf blight resistance from Allium roylei Stearn into onion (A. cepa L.). Euphytica 62: 127 $-133$.

de Vries, J. N., W. A. Wietsma and M. C. Jongerius. 1992 b. Linkage of downy mildew resistance genes $P d 1$ and $P d 2$ from Allium roylei Stearn in progeny of its interspecific hybrid with onion (A. cepa L.). Euphytica 64: $131-137$.

Hanelt, P. 1990. Taxonomy, evolution, and history. p.1-26. In: H.D. Rabinowitch and J.L. Brewster (eds.). Onions and Allied Crops, Vol. I . CRC Press, Boca Raton, Florida.

Hong, C. J., T. Etoh, B. Landry and N. Matsuzoe. 1997. RAPD markers related to pollen fertility in garlic (Allium sativum L.). Breeding Science 47: 359-362.

Holford, P., J. Croft and H. J. Newbury. 1991. Structural studies of microsporogenesis in fertile and male-sterile onion (Allium cepa L.) containing the cms-S cytoplasm. Theor. Appl. Genet. 82: 745-755.

Jones, H. A. and S. L. Emsweller. 1937. A male sterile onion. Proc. Amer. Soc. Hort. Sci.34: 582-585. 
Jones, H. A. and A. E. Clarke. 1943. Inheritance of malesterility in the onion and the production of hybrid seed. Proc. Amer. Soc. Hort. Sci. 43: 189- 194.

Jones, H. A. and L. K. Mann. 1963. Onions and their allies. p.34-36. Interscience Publishers, New York.

Kofoet, A., C. Kik, W. A. Wietsma and J. N. deVries. 1990. Inheritance of resistance to downy mildew (Peronospora destructor [Berk.]Casp.) from Allium roylei Stearn in the backcross Allium cepa L. $\times($ A. roylei $\times$ A. cepa $)$. Plant Breeding 105: 144- 149.

McCollum, G. D. 1971. Sterility of some interspecific Allium hybrids. J. Amer. Soc. Hort. Sci. 96: 359-362.

McCollum, G. D. 1974. Chromosome behavior and sterility of hybrids between the common onion, Allium cepa, and the related wild $A$. oschaninii. Euphytica 23: 699709.

McCollum, G. D. 1982. Experimental hybrids between Allium fistulosum and A. roylei. Bot. Gaz. 143: 238242.

Ochse, J. J. 1931. Vegetables of the dutch east indies. p.441 - 446. Archipel Drukkerij, Buitenzorg, Java.

Saini, S. S. and G. N. Davis. 1967. Compatibility in some Allium species. Proc. Amer. Soc. Hort. Sci. 91: 401409.
Saini, S. S. and G. N. Davis. 1969. Male sterility in Allium cepa and some species hybrids. Econ. Bot. 23: 37-49.

Schweisguth, B. 1973. Study of a new type of male sterility in onion, Allium cepa L. Ann. Amelior. Plant. 23: 221 253.

Tashiro, Y. 1984. Cytological studies on the origin of Allium wakegi Araki. Bull. Fac. Agr., Saga Univ. 56: 1-63.

Tashiro, Y., S. Miyazaki and K. Kanazawa. 1982. On the shallot cultivated in the countries of southeastern Asia. Bull. Fac. Agr., Saga Univ. 53: 65-73.

Tatebe, T. 1952. Cytological studies on pollen degeneration in male sterile onions. J. Japan. Soc. Hort. Sci. 21: 7375.

Ulloa-G, M., J. N. Corgan and M. Dunford. 1995. Evidence for nuclear-cytoplasmic incompatibility between Allium fistulosum and A.cepa. Theor. Appl. Genet. 90: 746- 754 .

van der Meer, Q. P. and J. N. de Vries. 1990. An interspecific cross between Allium roylei Stearn and Allium cepa L., and its backcross to $A$.cepa. Euphytica 47: 2931.

van Raamsdonk, L. W. D., W. A. Wietsma and J. N. de Vries. 1992. Crossing experiments in Allium L. section Cepa. Bot. J. Linn. Soc. 109: 293-303.

Allium galanthum Kar. et Kir. の細胞質を有するシャロット雄性不稔系統の育成の可能性

\author{
山下謙一郎・田代洋丞 \\ 佐賀大学農学部 840-8502 佐賀市本庄町
}

\begin{abstract}
摘要
Cepa 節野生種 A. galanthum Kar. et Kir. の細胞質を利用し たシャロット雄性不稳系統の育成の可能性を検討するため, これら2種間で連続戻交雑 (A. galanthumが細胞質提供親)を 行い, $\mathrm{F}_{1}, \mathrm{~B}_{1}, \mathrm{~B}_{2}$ および $\mathrm{B}_{3}$ について減数分裂, 花粉稳性お よび種子稔性の調査を行った. $\mathrm{F}_{1}$ ではわずかに稔性花粉が観 察されたが， $\mathrm{B}_{1}$ 世代では花粉不稔を示す個体が出現し， $\mathrm{B}_{2}$ および $\mathrm{B}_{3}$ ではすべての個体が花粉不稔となった. 戻交雑後

ため,この花粉不稔はシャロットの核とA. galanthum の細胞 質の不和合によって引き起こされると考えられた．種子稔性 は各世代の個体間で分離したが, 戻交雑が進むにつれて回復 した．葉緑体DNAの PCR-RFLP分析の結果，すべての戻交 雑後代が A. galanthum 由来の細胞質を有していた．本研究の 結果は，A. galanthumの細胞質を利用したシャロット雄性不 稳系統の育成が可能であることを示している.
\end{abstract} 代で花粉不稳となった個体の多くは正常な減数分裂を行った 